\title{
THE BLENDING EFFECT OF COALITE, COCONUT SHELL CHARCOAL AND GELAM WOOD CHARCOAL ON CALORIFIC VALUE
}

\author{
${ }^{1}$ Nukman, ${ }^{1}$ Riman Sipahutar, ${ }^{1}$ Irsyadi Yani and ${ }^{2}$ Taufik Arief \\ ${ }^{1}$ Department of Mechanical Engineering, Faculty of Engineering, Sriwijaya University, \\ ${ }^{2}$ Department of Mining Engineering, Faculty of Engineering, Sriwijaya University, \\ Jalan Raya Prabumulih km 32, Inderalaya (30662), South Sumatera, Indonesia
}

Received 2013-10-18; Revised 2013-11-08; Accepted 2014-03-03

ABSTRACT

The aim of this research is to scrutinize the effect of blend solid fuels consisting of coalite, coconut shell charcoal and gelam wood charcoal on calorific value. Coalite is the solid fuels made from coal that is mined from the earth, while coconuts shell charcoal and gelam wood charcoal are processed from natural plants. Coalite, coconut shell charcoal and gelam wood charcoal are solid fuels which was obtained from carbonization process or pyrolitic process of fuel material. Gelam wood charcoal has larger volatile matter and fixed carbon compared to coalite and coconut shell charcoal. These cause an increase in calorific value. A significant increase in calorific value obtained when coalite and coconut shell charcoal blended with a ratio of 75:25, with an increase of $8.38 \%$. With an equal blending ratio coalite and coconut shell charcoal and coconut shell charcoal with gelam wood charcoal can increase the calorific value up to $3.80 \%$ and $3.18 \%$ respectively.

Keywords: Coalite, Coconut Shell Charcoal, Gelam Wood Charcoal, Blending, Calorific Value

\section{INTRODUCTION}

The use of charcoal as primary energy began in the 19 th century. In the 20th century oil become the major fuel to replace charcoal as the world's principal energy source. It is well known that energy requirement continues to increase in line with the population increase (Khor et al., 2007).

Fuel such as gasoline, diesel and kerosene is nonrenewable and pollutes the atmospheric environment with its greenhouse effect. Their supply continuity is unpredictable and non-sustainable. If there is no change in the population's fuel consumption pattern, reserve fuel is predicted to be drained in less than 200 years (NTBD, 2007). Biomass is the fuel which is considered as renewable energy. The plants on this earth are endless sources of energy to consume. The blend of two types of fuel, renewable and non-renewable, is one possible solution.

One method that determines the quality of a certain fuel is proximate analysis, ultimate analysis and calorific value. Proximate analysis is conducted to determine the flame and burning reactivity characteristics of coal in which both characteristics are used for the basic boiler design. The results obtained from such analysis are moisture content, volatile matter, ash and fixed carbon (Speight, 2005) which is defined as material left-over from coal reduction. In Indonesia, the fuel mixture of palm kernel shells and coal is used in crude palm oil industry to heat water in a boiler. Both fuels are blended in order to increase the amount of their calorific values.

Several research related to the calorific value of the biomass fuels have been investigated by many researchers. Durian is a tropical fruit found in Southeast Asian countries. Wilaipon (2011) uses the husk of this fruit as agricultural residues for renewable energy sources. Nasrin et al. (2008), develop briquettes of oil palm biomass and sawdust. Powder and fibre of empty fruit bunches and palm kernel expellers which constitute parts of oil palm biomass are mixed with the sawdust. The presence of the sawdust Corresponding Author: Nukman, Department of Mechanical Engineering, Faculty of Engineering, Sriwijaya University, Jalan Raya Prabumulih km 32, Inderalaya (30662), South Sumatera, Indonesia 
proves to increase the calorific value of the briquettes. Awang and May (2009) mix some percentage of biomass charcoal and petroleum diesel and find that the calorific value of the mixture increase. Another research of renewable energy was conducted by Sukiran et al. (2011). The palm oil industry generates abundance of oil palm biomass such as mesocarp fibers, shells, Empty Fruit Bunches (EFB), frond, trunk and Palm Oil Mill Effluent (POME). They are made into bio-charcoal. The biocharcoal proves to contain more calorific value compared to that of Fresh Fruit Bunch (FFB).

In the utilization of solid fuel, calorific value must be noted as one of the considerations of large-scale and small-scale industrial consumers. Calorific value is the heat or specific energy released or produced during perfect combustion of a fuel, this energy is determined by burning a number of fine materials in an adiabatic bomb calorimeter equipment (Nukman and Poertadji, 2006).

Indonesia, as a country with the second largest rainforest in the world after Brazil, possesses the potential for abundant biomass materials. This research was conducted to blend two kinds of solid fuel and observe its effect on calorific value. Coalite was blended with coconut shell charcoal and gelam wood charcoal. In addition, gelam wood charcoal was also blended with coconut shell charcoal. This blending method was attempted to produce an optimal value and proposed as reference in the utilization of this blend technique.

\section{MATERIALS AND METHODS}

The solid fuel materials for this research were taken from three different locations. Coalite is a low rank coal which has undergone carbonization at a temperature of approximately $400^{\circ} \mathrm{C}$. Coalite is the base material for the production of super briquette produced by Tambang Batubara (PT), Tbk (incorporated), Tanjung Enim, South Sumatera (Sunarijanto et al., 2008). The briquette factory was formerly a joint venture between PT. Tambang Batubara and New Energy and Indsustrial Technology Development Organization (NEDO) Japan. Coconut shell charcoal was taken from a production centre in the area of Jaka Baring, Palembang, South Sumatera. Whereas gelam wood charcoal was taken from the charcoal industry centre at South Inderalaya, Ogan Ilir, South Sumatera. Gelam is a high-fiber white wood which usually grows in swampland.

The sample was prepared to consist of materials ground until (+)60(-)100 mesh or (+)250(-)150 $\mu \mathrm{m}$ meaning that the materials could be sifted through a 100 mesh sifter but did not pass through a 60 mesh one. To obtain a homogenous initial condition prior to testing, they were heated in a furnace at a temperature of $110^{\circ} \mathrm{C}$ for 1 (one) hour in order to minimize its moisture air to a maximum. This research involved two kinds of solid fuel to observe its effect on calorific value. Coalite was blended with gelam wood charcoal and with coconut shell charcoal. The gelam wood charcoal was also blended with coconut shell charcoal.

The proximate analysis used an air oven to heat samples with a weight of 1 gram contained in a measuring glass bottle. The air oven was used to measure the moisture air by referring to ASTM D3173 whereas Muffle Furnace was used to measure the ash weighed at 1 gram in an ash vessel by referring to ASTM D3174. This furnace was also used to measure the content of volatile matter with a sample weight of 1 gram which was placed in a crucible by referring to ASTM D3175. Calorific value analysis was conducted on 1 gram sample with a bomb calorimeter referring to ASTM D5865. Proximate analysis is conducted with a weight appropriate to each respective material whereas calorific value was conducted by an analysis which refers to a matrix of a blend between these three materials. Ratio is in percentage (\% of weight) which is: 100:0, 75:25, 50:50, 25:75 and 0:100. Proximate analysis and calorific value was conducted at the mineral technological research centre, Bandung Indonesia.

\section{RESULTS}

\subsection{Proximate Analysis}

The proximate analysis resulted in large percentages of moisture air and ash, two materials which were not expected. Volatile matters and fixed carbon are two principal elements for fuel. Volatile matter and fixed carbon are materials which are useful for combustion. Moisture air is an inhibitor for combustion and ash is a residue of combustion. The results of proximate analysis are shown in Fig. 1.

\subsection{Calorific Value Analysis}

The calorific value analysis can be described in a relation graph between calorific value and blend ratio (\%) as seen in Fig. 2. The highest calorific value was obtained from gelam wood charcoal which was $7258 \mathrm{kcal} \mathrm{kg}^{-1}$, followed by coconut shell charcoal and coalite of 6979 and $5944 \mathrm{kcal} \mathrm{kg}^{-1}$ respectively. The calorific value of gelam wood charcoal was appropriate considering that material wasted from the sample, such as water and ash, was less than the other two materials. Water would evaporate whereas ash would remain as combustion residue. 


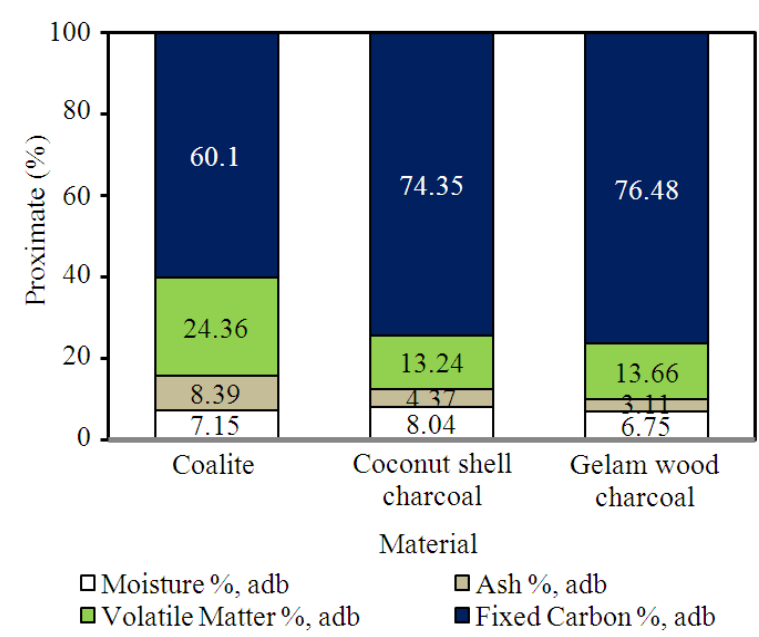

Fig. 1. Result of proximate analysis for coalite, coconut shell charcoal and gelam wood charcoal

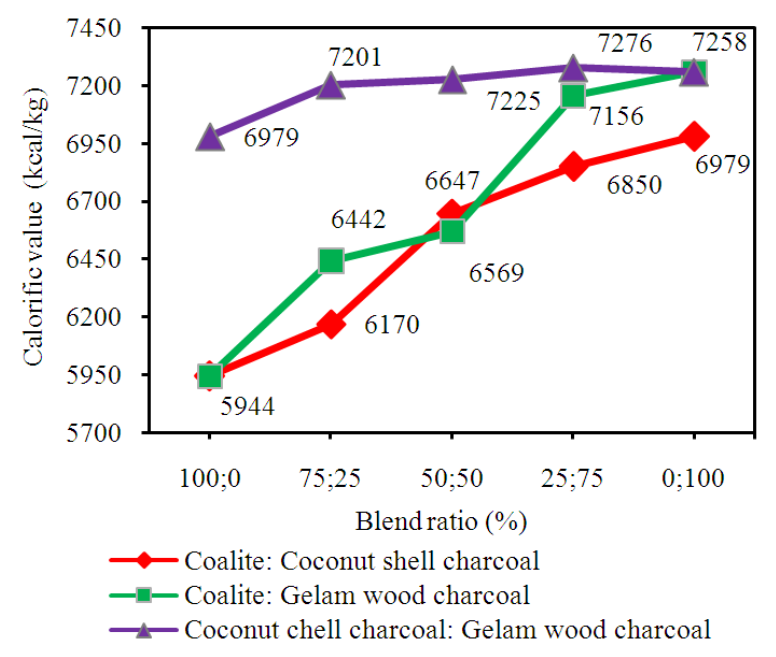

Fig. 2. The relation of calorific value and blend ratio

\section{DISCUSSION}

\subsection{Proximate Analysis}

Figure 1 presents, the quantity of volatile matter in coalite was larger than the other two materials; this indicated that coalite had a larger initial combustion ability because the volatile matter contains gases such as hydrogen, carbon monoxide and gases which are easily combustible such as methane and other hydrocarbons.

Tar and incombustible gases, such as carbon dioxide and steam, were also present in this volatile matter (Speight, 1994; Nukman, 2007). Should the percentage of both principal elements, volatile matter and fixed carbon, be added then gelam wood charcoal is the material which has a percentage larger than $90.14 \%$, followed by coconut shell charcoal and coalite each respectively at 87.59 and $84.46 \%$.

The relatively lower moisture air in gelam wood charcoal compared to the other two materials indicated that gelam wood charcoal combustion could begin earlier, but this did not mean that gelam wood charcoal was more combustible because its volatile matter was smaller compared to coalite.

\subsection{Calorific Value Analysis}

Figure 2 presents a non-linear relation of calorific value of the three blended sample material. The effect of fixed carbon on the calorific value has been discussed before. The higher amount of fixed carbon increased the calorific value of coal (Poertadji et al., 2006). This was clearly influenced by the volatile matter in each sample material. There was quite a large increase in calorific value in the blend of coalite and coconut shell charcoal in a percentage blend ratio of 75:25, or an increase of $8.38 \%$. With an equal ratio blend, the blend of coalite and coconut shell charcoal achieved an increase of $3.80 \%$, whereas the blend between coconut shell charcoal and gelam wood charcoal reached an increase of $3.18 \%$. This indicates that if coalite was blended with gelam wood charcoal its calorific value increase was larger compared to both kinds of blend with a ratio of $75: 25$. Figure 2 presents that if coalite is blended with gelam wood charcoal its calorific value increase was larger. This was due to the fact that the calorific value of gelam wood charcoal was larger compared to that of the other two materials. Hence, the proximate analysis results indicate that water and ash content had a significant effect on the calorific value. The increase in calorific value according to the result of the mixing has been done by other researchers. Awang and May (2009) and (Nasrin et al., 2008), where the greatest value can increase the lower.

\section{CONCLUSSION}

The proximate analysis shows that the content of volatile matters and fixed carbon of gelam wood charcoal was not larger compared to that of coconut shell charcoal and coalite. Neither the calorific value of gelam wood charcoal was larger than that of the other two materials. This shows that the total amount of volatile matter and fixed carbon was influential to the calorific value and, therefore, the water and ash content were 
influential to the calorific value. Coalite at a blend ratio of $75: 25 \%$ with gelam wood charcoal had a larger calorific value than other blends.

This study did not investigate the field of the power plants or foundries which is often use coke as a fuel. However, the research has been able to provide real data of the blending two kinds of solid fuels; biomass and coalite that has generated a new calorific value. This research needs to be continued with the amount of combustion temperature that can be reached and investigated the influence of this blending of the flue gas emissions.

\section{ACKNOWLEDGMENT}

The researchers acknowledge the head of department and laboratory staff of Mechanical Engineering Department, Sriwijaya University, Indonesia for all their supports.

\section{REFERENCES}

Awang, R. and C.Y. May, 2009. Charcoal-oil mixture as an alternative fuel: A preliminary study. Am. J. Applied Sci., 6: 393-395. DOI: 10.3844/ajassp.2009.393.395

Khor, A., C. Ryu, Y.B. Yang, V.N. Sharifi and J. Swithenbank, 2007. Straw combustion in a fixed bed combustor. J. Fuel, 86: 152-160. DOI: 10.1016/j.fuel.2006.07.006

Nasrin, A.B., A.N. Ma, Y.M. Choo, S. Mohamad and M.H. Rohaya et al., 2008. Oil palm biomass as potential substitution raw materials for commercial briquettes production. Am. J. Apllied Sci., 5: 179183. DOI: 10.3844 /ajassp.2008.179.183
NTBD, 2007. Alternative fuels from plants as a substitute for Oil and Gas. Penebar Swadaya Publishers, National Team for Biofuel Development.

Nukman and S. Poertadji, 2006. The increasing of calorific values of bituminus coal by using waterpalm oil agglomeration process. J. Technol., 20: 106-113.

Nukman, 2007. Water-oil agglomeration process to decreasing the level of ash and sulfur contents and increasing the calorific values of semi anthracite, bituminous and sub-bituminous coals. PhD Thesis, Indonesia University, Jakarta, Indonesia.

Poertadji, S., Nukman and M. Hikam, 2006. The effect of the agglomerating of water-oil palm to carbon content and calorific value of semi-anthracite, bituminous and sub-bituminous coals. J. Indonesia Materials Sci., 7: 68-74.

Speight, J.G., 1994. The Chemistry and Technology of Coal. 2nd Edn., CRC Press, ISBN-10: 0824792009, pp: 664.

Speight, J.G., 2005. Handbook of Coal Analysis. 1st Edn., John Wiley and Sons, Inc., Hoboken, ISBN10: 0471718505, pp: 240.

Sukiran, M.A., L.S. Kheang, N.A. Bakar and C.Y. May, 2011. Production and characterization of bio-char from the pyrolysis of empty fruit bunches. Am. J. Applied Sci., 8: 984-988. DOI: 10.3844/ajassp.2011.984.988

Sunarijanto, H.R., B.L. Adi, T. Simbolon, B. Sitanggang and I. Pujono et al., 2008. COAL: Business Guide PT Bukit Asam. PTBA, Jakarta.

Wilaipon, P., 2011. Durian husk porperties and its heating value equation. Am. J. Apllied Sci., 8: 893896. DOI: 10.3844 /ajassp.2011.893.896 